
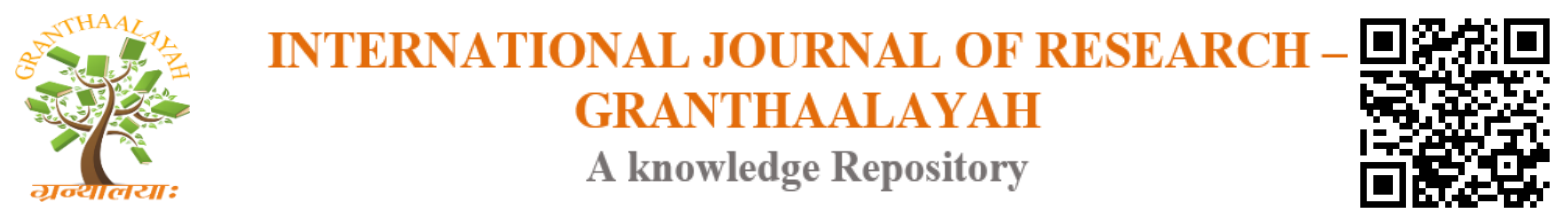

Social

\title{
IMPROVE THE EDUCATIONAL SYSTEM OF DEVELOPING COUNTRIES
}

\author{
AlidaVallejo-López ${ }^{1}$, Magaly Peñafiel-Pazmiño ${ }^{2}$, Ana Maria Viteri ${ }^{3}$ \\ ${ }^{1}$ University of Guayaquil-Ecuador. Faculty of Medical Sciences \\ ${ }^{2}$ ECOTEC Technological University. Faculty of Engineering \\ ${ }^{3}$ University of Guayaquil, Ecuador Faculty of Medical Sciences
}

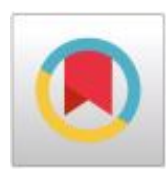

\begin{abstract}
Education plays a fundamental role in the academic formation of the citizens of a country, the authorities, governments have the responsibility and the obligation to give citizens the possibility to prepare and grow in knowledge to work for the welfare of society. The objective of this article is to reflect on the current situation to access the University in countries that consider the entrance exam to make a change proposal. The method used has been the observation, review of articles, database impact journals and authors specialized in the subject. The results obtained after the analysis performed are clear since the law helps reason, in this article. Conclusion. - Governments must provide the facilities to enter the universities of each country, for this they must establish new policies and a solution that allows the entire population to fulfill their desire to study.
\end{abstract}

Keywords: Higher; Education; Freedom; Income for Students.

Cite This Article: AlidaVallejo-López, Magaly Peñafiel-Pazmiño, and Ana Maria Viteri. (2019). "IMPROVE THE EDUCATIONAL SYSTEM OF DEVELOPING COUNTRIES." International Journal of Research - Granthaalayah, 7(8), 69-77. 10.29121/granthaalayah.v7.i8.2019.640.

\section{Introduction}

Education plays a fundamental role in the academic training of citizens of a country, authorities and governments have the responsibility and the obligation to give citizens the possibility of preparing and growing in knowledge, to work for the welfare of society and achieve a better future. "In general, Social Responsibility can be defined as the active and voluntary contribution to social, economic and environmental improvement by companies generally with the objective of improving their competitive and valuation situation (...)" (1). The objective of this article is to make a reflection of the current situation to access the University in countries that apply the entrance exam to make a change proposal.

The problem that occurs every day in the Education Institutions in several countries of Latin America, is present in Ecuador, at all levels, both primary school, high school, and higher, affecting a large sector of the population, must be analyzed, as it requires short-term solution proposals. 
Especially in the upper level, where perhaps the biggest problem is, by not allowing the entry of all students who aspire to obtain a quota to enter a career that allows them to access a third level degree, this situation occurs as a result of not passing the so-called entrance exam that has been imposed in Ecuador since 2012 and in many Latin American countries in the last decade being mandatory for students who are about to finish high school and it is only through this exam that they can Access to study at a University in which place in your country.

During this process, in many cases, some students, who achieve high scores, do not have exactly the careers they request in the first instance, because there are no places in that race, so they are directed to the second or third option requested, while the First option, which was its main objective or goal is not assigned in most cases, because there is no availability of classrooms and teachers, which reveals that there is not enough infrastructure or the availability to enable them, in the different areas of the knowledge This situation is due to the great demand to enter a Higher Education Institution.

In Ecuador, improving the quality of Higher Education is a task that began a decade ago with the government of economist Rafael Correa, working on programs aimed at improving the human talent that is formed in the University Education classrooms. The agency in charge is called the Ministry of Higher Education, Science, Technology and Innovation (Senescyt).

When talking about improving education, aspects related to teaching strategies, technological resources, educational environments, society participation, policies in favor of capacities and updates, methods, but in no way to the application of exclusionary policies to any group of society, consider methods that discriminate, or "regulate" an inalienable right without obligations, be the excuse that justifies the incompetence of those responsible for supplying infrastructure, personnel and supplies necessary for national government education .

On the other hand, there is always the possibility of covering state failures with private education that is generally of good quality, but not the entire population can access it, usually because of the high costs they represent.

The objective of this article is to make a reflection of the current situation to access the University in countries that examine the entrance exam to make a change proposal.

The method used has been the observation, review of articles, database impact journals and authors specialized in the subject. The results obtained after the analysis performed are clear as the law assists reason, in this article.

\section{Developing}

Training a competent professional is a complex goal, but achievable during the educational process. They should think about new curricular proposals, a training of transformative science educators, and recognize that scientific education must expand its borders and build bridges between what happens in classrooms, with non-formal scenarios, science clubs, museums and science spaces (2) 
If you want to train better citizens and a more just society, you should completely eliminate these archaic procedures that only stigmatize the student by dehumanizing him and turning him into a number, which indicates whether you are better or worse, on issues that are not the fundamental basis of a society, provoking in many cases social resentment, frustrated and diminished people in their personal self-esteem, that later could be dedicated to vent their frustrations with the society committing undue acts.

For the high demand of students who aspire to enter universities in Ecuador, the laws indicate that everyone has the right to an education, welfare, equity and that it is a duty of the state, however this situation persists and every time it goes away accentuating the great social problem, in this situation perhaps sr could find one or several proposals for possible solution, among them, endow in all regions of the country with Institutions of Higher Education that can accommodate the growing population that needs to study.

It is known that knowledge constitutes an intangible value for the human being, therefore it must be reflected that its importance lies in the fact that people who access a higher education have a better understanding of issues that affect humanity in various fields. To respond to the requirements of higher education of the 21 st century, essential transformations are required to improve the educational-institutional model in order to respond effectively and with relevance to the demands of this new context that evolves day by day in the world current. (3)

The Constitution of the Republic of Ecuador 2008 in its Art. 3. States: The State's primary duties are: To guarantee without discrimination the effective enjoyment of the rights established in the Constitution and in international instruments, in particular education, health, food, social security and water for its inhabitants.

Art. 26. - Education is a right of people throughout their lives and an inescapable and inexcusable duty of the State. It constitutes a priority area of public policy and state investment, guarantee of equality and social inclusion and an indispensable condition for good living. Individuals, families and society have the right and responsibility to participate in the educational process.

Art. 27.- Education will focus on the human being and will guarantee its integral development, within the framework of respect for human rights, the sustainable environment and democracy; it will be participatory, mandatory, intercultural, democratic, inclusive and diverse, of quality and warmth; promote gender equality, justice, solidarity and peace; It will stimulate critical sense, art and physical culture, individual and community initiative, and the development of skills and abilities to create and work. Education is indispensable for knowledge, the exercise of rights and the construction of a sovereign country, and constitutes a strategic axis for national development. (4)

While article 28 guarantees universal and free access to the third level of higher education, including, finally, article 29.- guarantees freedom of education, freedom of education in higher education and the right for people to learn in Your own language and cultural environment. Mothers and fathers or their representatives will be free to choose an education for their daughters and sons in accordance with their principles, beliefs and pedagogical options. 
There are many people who in the course of their lives require an opportunity to be better and this procedure (entrance exam) denies them. Equity should not be only for the disabled, for foreigners or for those with different tendencies, it should be for everyone, otherwise it is not equity. Understanding the relationship between the socioeconomic environment and student performance facilitates the analysis of the distribution of educational opportunities. (5)

The regulations in force in Ecuador and in Cuba require demanding entrance exams, with the stated purpose of stimulating the dedication to the study of secondary students who aspire to a subsequent university graduation. The entry regime in Argentina is original, since it does not apply in almost any country in the world: the recent enacted Law 27,204 excludes the entrance exam. The Argentine university graduation is very low and is located behind that of Cuba, Colombia, Brazil and Chile. (6)

Therefore, this discriminatory process must be abolished, to open the way to a more just and open society to the possibility of having more people studying, to prevent them from wandering in the street, criminalizing, hurting society or filling prisons. For this, the population growth must be balanced directly with the growth of the Education Institutions of all levels, primary, middle and higher, that is the true mission of the Governments, since all other aspects of education start that are integrated to form a respectful and humane productive society.

From the economic point of view, if these articles enshrined in the Constitution of the Republic of Ecuador are fulfilled, the expenses that are generated in education can be deducted and the comparison with those generated in the judicial processes and centers of rehabilitation that is where every time the cases are increased in which people who claim conditions of poverty or lack of work are involved for not having produced frequent problems affected with society.

It is understandable the arguments that state that they maintain a free education for all the high cost applicants and that is why the entrance exam is established, however the solution could be given in this sense by contributing to somehow pay the expenses generated, without constituting a disproportionate item, this would be justifiable if everyone had the tranquility and ease of access to universities near their places of origin, preparing to contribute to the growth and production of their region.

Within this scheme it would be important to mention the statement of the work "The challenges of the public university in Latin America and the Caribbean: The nodal principle of the proposed change is related to the formation of a citizen with full rights and broadly participatory, with an education that serves and is useful to you, in the broadest and most social sense of the term, to be constructed in a socially autonomous way both in your personal development and in that of your knowledge, knowledge, skills, values and competencies, in a conscious and review. In the face of exclusion, we propose a change criterion that is comprehensive and places the educational process on the subject as a fundamental factor of transformation.

With an educated and participatory citizenship, one can aspire to a different and better world. It is not a singular or recent aspiration, but of centuries, which has deformed to the maximum in recent years, considering education as a privileged space for the formation of consumers. Education is more an intention of the future, a duty to be and the aspiration to form a better generation to ours. 
This is the sense of the change that is proposed: to move from teaching and the reiteration that learning is fundamental, to the (future) idea that universities must be a central part of the organizational structures of new production platforms and knowledge transfer, to make possible a socially broad autonomy regime that articulates the activities of higher education institutions at all levels, their degrees, trajectories and recognition with society. (7)

In the process of adaptation and change to integrate into the new contexts of the University, it will always be important to consider the leveling period as the link that helps to balance the knowledge gaps that may exist in the student, strengthening their ties with their future career, also improving their capacity for communication, research, creativity in their performance and recognizing their social commitment to the country. "We need to improve our training, research, innovation, management and financing strategies and policies, eliminating ideological barriers and prejudices, taking advantage of successful experiences and opportunities offered in new technologies." (8)

Another aspect to consider is to improve the training of teachers and provide facilities for their purpose, everything that works in a friendly environment will work better, teachers should not be distracted from their administrative tasks of WORK BY. Or else, quality education is necessary. Consider the need to promote transformations in three directions: teaching, research and reflection; move from models focused on the coach to models focused on the student of pedagogy and the community. In teaching, the focus would be on who the student is, how he does it and how the trainer can facilitate this process (9)

It is important to try to reach students in the best way to achieve a better adaptation in their new study scheme to better incorporate it also in a learning system in which research and science are essential to deepen the knowledge acquired. The communication of science is the set of communicative actions used to transmit the processes, knowledge and results of scientific work. This process can be directed to a community of specialists or public segments. (10)

The strategic role of higher education is recognized, both in the generation of knowledge and technological innovations, and in the training of professionals who control and contribute to the understanding and solution of environmental problems, it is necessary from the bachelor's degree to design and implement programs to favor The formation of skills for the productive development of research and innovation activities. (11)

The entire educational community, as well as each human being, requires quality of life and the more content considered in each period, the less it will be possible to LEARN, to think that otherwise, it is a big mistake, the work days MUST be reorganized., production Educational knowledge has to face the challenges of major changes in science, technology and society.. (12)

The reflections made so far lead to a statement: There can be no social justice and educational equity without breaking down the barriers that impede the full use of education by all. Both national policies and private initiatives should be judged from this perspective. (13)

The relationship between the teacher, the student and the family make up the perfect educational training formula, especially in the early stages of learning. Therefore, improving interpersonal communication relationships between teachers and society is an aspect that must be worked on, 
since everyone seeks to achieve the same objective as forming a good citizen and a responsible active professional future that serves society and the country.

\section{Conclusion}

All people must have the freedom to access to study at a University anywhere in their country at the time they need it, to comply with the law and equity enshrined in the Constitution of the Republic of Ecuador, therefore the Governments must provide the facilities for this purpose, which will result in prepared and productive people, reducing crime levels, and generating well-being and prosperity for society.

\section{Proposal}

\section{Improve the Country Education System in Roads of Development: Ecuador}

For an equitable, ethical and humanistic education.

The following proposal originates when analyzing the problem that is presented every day in the Education Institutions in Ecuador, including all levels, both primary and basic baccalaureate. But especially at the higher level by the so-called entrance exam to study a career that allows you to access a third level degree.

It is considered that the right to study should not be manipulated on the pretext of evaluations that end up restricting free access to education in the countries of Latin America or the world.

All people should have the freedom to access to study at a University anywhere in their country, at the time they need it; therefore, governments must provide the facilities for this purpose that will ultimately result in prepared and productive people. Decreasing levels of crime, which results in the well-being of society.

\section{Objectives}

\section{General}

To form a good citizen respectful of his neighbor, of life, of the laws, with an awake, reflective, creative, investigative and innovative mind capable of organizing information and working as a successful professional, aware of his social responsibility with society and the world

\section{Specifics}

Promote changes in the improvement of the country's educational processes, in the new millennium, to train new professionals to be developed in the new context of the future.

Expand educational coverage at all levels for the entire population without discrimination, to comply with the current Constitution.

Train and update teachers' knowledge to strengthen their communication skills, to interact in the global context of science, research and innovation. 
Motivate the development of students' abilities in the classroom that facilitates efficient performance in the educational environment.

Improve the relationship between the teacher and the student in the process of educational training at all levels of training.

This proposal consists of three axes of work and six fundamental principles, which specifically affect the aim of being a better society with citizens trained and committed to serving their country and the world.

\section{Work Axes}

\section{Curricular Design Axle}

Promote the improvement of curriculum design, the development of critical thinking, creativity, innovation, humanism, values, ethics, with a broad worldview and research, in addition to the essential subjects of each career.

\section{Training Axis of the Human Being}

Consolidate human values, as basic pillars on which the good citizen is formed during his educational process, to serve society and the world in a responsible way and committed to give a contribution to knowledge

\section{Axis of Educational Policies}

Develop real educational policies with equal opportunities for all citizens at all levels of education, without restrictions due to prerequisites for entering specific educational institutions and for this the Government must supply the growing population demand that requires quality education.

\section{Fundamental Principles to Improve Education in Ecuador. 2019}

Policies Educational policies aimed at equating the learning opportunities of all citizens who aspire to overcome and reach a level of technical and professional preparation of the third or fourth level, creating, building, enabling or transferring, new infrastructure that supplies the growing demand for population.

Strengthen the values, as basic pillars on which the character of the good citizen will be formed from the early stages of his life, in a theoretical-practical way until completing his educational process, aimed at cultivating a humanistic, ethical, respectful and professional professional. Responsible and honest future that serves society and the world.

Strengthen inclusive education related to the reality of our country and not based on foreign models that degenerate the culture and customs of our population, causing the loss of ancestral identity and self-esteem.

Constant training programs for teachers in primary, secondary and preparatory schools so that they are updated on the use of teaching tools and pedagogical strategies at least once a year, in an equitable manner and with wide coverage. 
Develop various teaching and evaluation methods that consider the cultural characteristics of the population and individuals of each person, depending on their personal and group performance, in both their realization, creative initiatives and their intentionality and willingness to serve society. Foster the love of their country, their customs, their roots, empowering them of the knowledge of their origin, promoting the pride of being Ecuadorian and Latin American with a great amount of knowledge that must be strengthened and scientifically argued to be recognized by everyone. International community.

These principles should make them available to all levels of education in the country, to achieve high-quality academic training, which provides well-being and prosperity to the community and society in general, through the training of competent professionals and committed citizens with your country.

\section{References}

[1] Óscar J González Alcántara 2010 La Responsabilidad Social en Las Universidades Españolas Editor Dr. D. Óscar J. González Alcántara, Dr. D. Ignacio Fontaneda González, Dr. D. Miguel Ángel Camino López, Da. Araceli Antón Lara

[2] Gonzalez-Argote, J., \& Garcia-Rivero, A., \& Dorta-Contreras, A. (2016). Producción científica estudiantil en revistas médicas cubanas 1995-2014. Primera etapa. Investigación en Educación Médica, 5 (19), 155-163. http://www.redalyc.org/pdf/3497/349746529004.pdf

[3] GOMEZ, J.; DIEGUEZ, P.; GOMEZ 2014 Motivando el interés por la investigación científica en estudiantes de educación media superior Congreso Iberoamericano de Ciencia, Tecnología, Innovación y Educación D ISBN: 978-84-7666-210-6 - Artículo 353 Buenos Aires Argentina Benemérita Universidad Autónoma de Puebla. México.

[4] Asamblea Nacional Constitución de la República del Ecuador 2008

[5] OECD SANTILLANA VOLUMEN 2 EDICION ESPAÑOLA 2012 Informe PISA 2009: 2011 Superación del entorno social Equidad en las oportunidades y resultados del aprendizaje (Volumen II).

[6] Alieto Aldo Guadagni Ingreso a la universidad en Ecuador Cuba y Argentina 2016 http://www.rlcu.org.ar/recursos/E_0000046_004_cea_numero_44.pdf

[7] Mera Carolina Acosta Silva Adrián | Atairo Daniela | Camou Antonio | Andrés Donoso Romo | Dragnic García Mía | Pinheiro Barbosa Lia | Higuera Rubio Diego Mauricio | Piñeros Lizarazo Robinzon | Álvarez Satizabal Gineth Andrea | Cano Menoni Agustín | Axel Didriksson - Los desafíos de la universidad pública en América Latina y el Caribe / Ciudad Autónoma de Buenos Aires: CLACSO, 2015. Takayanagui

http://biblioteca.clacso.edu.ar/clacso/posgrados/20150722114530/LosDesafiosDeLaUnivPublica. pdf

[8] Para Rodríguez Ignacio -Santana El Modelo de Futuro de Gestión de la Salud, Propuestas Para Un Debate Editorial Visión Libros, 2012

[9] González-Vallejos, M. (2018). El estudio del formador latinoamericano: un campo de investigación 'en construcción'. Magis. Revista Internacional De Investigación En Educación, 10(21), 35-54. https://doi.org/10.11144/Javeriana.m10-21.eflc

[10] http://revistas.javeriana.edu.co/index.php/MAGIS/article/view/21774

[11] Castillo Vargas Andrés Dr. Importancia de la divulgación en la comunicación científica académica Instituto de Investigaciones Psicológicas Escuela de Psicología Universidad de Costa Rica http://www.ebci.ucr.ac.cr/sites/default/files/descargables/castillo_vargas_andres_importancia_de_ la_divulgacion_en_la_comunicacion_cientifica_academica.pdf 
[12] Perdomo, Irene Victoria, \& Martínez Calvo, Silvia. (2010). Methodological strategy for the evaluation of professional competencies in Hygiene and Epidemiology specialists. Revista Cubana de Salud Pública, 36(2), 142-147. Recuperado en 11 de enero de 2018, de http://scielo.sld.cu/scielo.php?script=sci_arttext\&pid=S086434662010000200007\&lng=es\&tlng=en.

[13] Rincón Ramírez Carlos LA FORMACIÓN DE INVESTIGADORES EN EDUCACIÓN: RETOS Y PERSPECTIVAS PARA AMÉRICA LATINA EN EL SIGLO XXI Universidad Autónoma de Chiapas, Revista Iberoamericana de Educación (ISSN: 1681-5653) México.

[14] Silva Laya Marisol: 2019 México, Tres iniciativas de equidad educativa universitaria en la ciudad de México. Revista Mexicana de Investigación Educativa vol. 24, núM. 80, pp. 43-68 (Issn: 14056666 Disponible en: http://comie.org.mx/revista/v2018/rmie/index.php/nrmie/article/view/1237/1185 marisol.silva@ibero.mx

*Corresponding author.

E-mail address: alida.vallejol@ug.edu.ec/ositos_3@yahoo.es 